\title{
Importance of Gamma Irradiation, Micronutrient Mixtures and Their Application Methods for Improving Faba Bean (Vicia Faba L) Growth and Yield.
}

\author{
Iman A.A. Farag ${ }^{1}$, Noha E. Eliwa ${ }^{1}$ and A.A.H. El Khawaga ${ }^{2}$ \\ ${ }^{I}$ Natural Products Department, National Center for Radiation Research and Technology, Nasr City, Cairo, \\ Egypt. \\ ${ }^{2}$ Agron. Dept., Fac. Agric., Zagazig Univ., Egypt
}

\begin{abstract}
Importance of gamma irradiation doses; zero, 15, 30 and $60 \mathrm{~Gy}$, in addition to three micronutrient application methods i.e. coating, soaking and spraying, as well as micronutrient mixtures, which were control, $\mathrm{Fe}+\mathrm{Zn}+\mathrm{Mn}$ and $\mathrm{Fe}+\mathrm{Zn}+\mathrm{Mn}+\mathrm{Mo}$ on growth, yield and yield attributes of Faba bean cultivar Sakha 1, was investigated during 2010-2011 and 2011-2012 seasons. The work was conducted in an experimental field at Balbees district, Sharkia Governorate, Egypt. The experimental farm soil was sandy texture.

Recorded results showed that gamma irradiation dose of 30 Gy was the most effective, while dose of 60 Gy was the most depressive on number of nodules/ plant and day weight of nodules (mg/plant) at 50 and 75 DAS; leaf area /plant and LAI at 75 DAS; leaf content of chlorophyll A, B and carotene at 75 DAS; number of branches, Pods and seeds/ plant; Seed index as well as seeds, straw and biological yields/ fad. In view of micronutrient application methods, foliar spraying method was the most enhancing for the above-named traits followed by seed soaking method, while seed coating method was the least. Both micronutrient mixtures outbraved the control regarding the aforementioned characters; results averred that appliance of $(\mathrm{Fe}+\mathrm{Zn}+\mathrm{Mn})$ micronutrient mixture was more effective than application of $(\mathrm{Fe}+\mathrm{Zn}+\mathrm{Mn}+\mathrm{Mo})$ micronutrient mixture, on each of growth and yield trails studied.
\end{abstract}

Key words: Gamma Irradiation Micronutrient, Faba Bean, Growth and Yield.

\section{Introduction}

Broad bean (Vicia faba L.) is one of the important legumes in the Middle Eastern countries. It can be used as a dietary item alone or can serve as a potential supplement to cereal diets, especially for the preparation of inexpensive protein rich food for children (Al-Kaisey et al., 2002) ${ }^{[1]}$. In Egypt, faba bean is among the main nutritional source of plant protein (Bakry et al., 2011) ${ }^{[2]}$. Several studies have indicated that irradiation technique is one of prime importance in agriculture for improvement not only the productivity of crop but also for increasing the nutritive value of produced crops. It is well known that the modification in plant growth and yield imposed by any of the environmental stresses is considered to be a reflection of certain alterations in some metabolic events in tissue. Consequently, it is thought that seed irradiation may affect some of the biochemical regulatory mechanisms involved in seed germination and plant growth. The plant growth characteristics and yield were reported to be variously affected inconsequence of gamma irradiation of seeds pre-sowing (Abou ElYazied, 2011) ${ }^{[3]}$; (Soliman and Abd El-Hamid, 2003) ${ }^{[4]}$.

In the last two decades, several investigators in Egypt reported positive response of different field crops (faba bean) to micronutrient fertilization (El- Fouly et al., 2011) ${ }^{[5]}$. Micronutrients are required in small amounts and they affect directly or indirectly photosynthesis, vital processes in higher plant such as respiration, protein synthesis, reproduction phase (Marschner, 1995) ${ }^{[6]}$.El-Akabawy et al. $(2001)^{[7]}$ stated that the beneficial effects of micronutrients application on maize were recorded by many workers. Manganese has an essential role in amino acid synthesis by activating number of enzymes particularly decarboxylases and dehydrogenases of the tricarboxylic acid cycle. Ashoub et al., (1998) $8^{[]}$showed that using maize grain coating with $\mathrm{Mn}$ increased plant height, dry weight /plant, number of green leaves /plant, weight of 100 -grains, grain yield, straw yield, Mn uptake and protein content in grains. El-Gizawy $(2000)^{[9]}$ found that the highest grain yield was recorded by foliar application or grain soaking with Mn. Iron is a constituent of many enzymes involved in the nutritional metabolism of plant (Kabata-Pendias and Pendias 1999) ${ }^{[10]}$. Zinc plays an important role as a metal component of enzymes (superoxide dismutase, carbonic anhydrase an polymerase) or as a functional, structural, or regulate RNA cofactor of a large number of enzymes (Kabata-Pendias and Pendias 1999) ${ }^{[10]}$. Kanwal et al., (2010) ${ }^{[11]}$ found that zinc application to soil had a positive significant effect on grain yield of maize. Rego et al., $(2007)^{[12]}$ reported an increase in grain yield of maize by $\mathrm{Zn}$ application. Molybdenum is known to be a relatively mobile nutrient in the plant system and readily concentrated by plants (Clarkson and Hanson, 1980) ${ }^{[13]}$. 
The aim of the present investigation is to study the effect of gamma irradiation, micronutrient application methods and micronutrient mixtures (control, Fe+ $\mathrm{Zn}+\mathrm{Mn}, \mathrm{Fe}+\mathrm{Zn}+\mathrm{Mn}+\mathrm{Mo}$ ) on faba bean growth and yield.

\section{Materials and Methods}

The field experiment was conducted during the 2 consecutive seasons of 2010-2011 and 2011- 2012 in an experimental field at Belbeesdistric, Sharkia Governorate, Egypt. The experimental farm soil was sandy texture, comprising of $79.51 \%$ sand, $10.33 \%$ silt and $10.13 \%$ clay, $0.82 \%$ organic matter, available phosphorus $10.11 \mathrm{ppm}$, available nitrogen21.91 ppm, available K 153.40ppm with $\mathrm{PH}$ of 7.71, the experiment was laid out in split-split plot design with four replications. Irradiation treatments $(0,15,30$ and $60 \mathrm{~Gy})$ were assigned to the main plots, while, micronutrients application methods i.e. (coating, soaking and foliar) were arranged in the subplots, mixture of micronutrients i.e. (control, $\mathrm{Fe}+\mathrm{Zn}+\mathrm{Mn}, \mathrm{Fe}+\mathrm{Zn}+\mathrm{Mn}+\mathrm{Mo}$ ) were located in the sub-sub plots. For coating method, micronutrients were added at the rate of $0.3 \mathrm{~g} / \mathrm{kg}$ seeds for $\mathrm{Fe}, \mathrm{Zn}$ and Mn, however Mo was applied at $0.039 \mathrm{~g} / \mathrm{Kg}$ seeds, regarding foliar or soaking application methods, micronutrients concentration was $300 \mathrm{ppm}$.

Micronutrients were added in the form of EDTA except molybdenum, which was added as ammonium molybdate. In the foliar spray treatments, micronutrients were sprayed twice, the first when plants aged 30 days and the second was on 45 days from sowing. Seeds were soaked in micronutrients solution for four hours.

Irradiation was performed using $\mathrm{Co}^{60}$ source from unit gamma chamber 4000, at the National Center for Radiation Research and Technology. The experimental plot area was $12.25 \mathrm{~m}^{2}$, contained 6 ridges with $3.5 \mathrm{~m}$ length and each ridge was $60 \mathrm{~cm}$ apart. The distance between hills was $30 \mathrm{~cm}, 2$ plants per hill. Seeds of faba bean Sakhal cultivar were obtained from legume crops research institute, Giza, Egypt, and hand sown on $17^{\text {th }}$ Oct. and $20^{\text {th }}$ Oct. in both seasons.

Calcium superphosphate $\left(15.5 \% \mathrm{P}_{2} \mathrm{O}_{5}\right)$ was used as a source of phosphorus at the level of $30 \mathrm{Kg} \mathrm{P}_{2} \mathrm{O}_{5} /$ fad., added during soil preparation . Ammonium nitrate $(33 \% \mathrm{~N})$ as a source of nitrogen was applied at the level of $20 \mathrm{Kg} \mathrm{N} / \mathrm{fad}$, also potassium sulphate $\left(48-52 \% \mathrm{~K}_{2} \mathrm{O}\right)$ was used as a source of potassium on the level of $24 \mathrm{~kg}$ $\mathrm{K}_{2} \mathrm{O} / \mathrm{fad}$, both nitrogen and potassium fertilizers were supplied after 20 days from sowing. Flood irrigation system was used. All other cultural practices were carried out as recommended for faba bean production in both seasons.

At both 50 and 75 days after sowing (DAS), number of nodules / plant and weight of nodules (mg/plant) were recorded from random sample of five plants for each experimental unit. Leaf area $\left(\mathrm{cm}^{2} / \mathrm{plant}\right)$ was measured at 75 DAS, then leaf area index was calculated.Also, at 75 DAS, chlorophyll A, chlorophyll B and carotene were determined according to (Metzneret al., 1965) ${ }^{[14]}$

At harvest, random sample of five guarded plants from each sub-subplot was taken and plant height $(\mathrm{cm})$, number of branches and pods/ plant, number of seeds/ pod, seed weight (g/ plant), were measured. 100- Seed weight $(\mathrm{g})$ for each plot was recorded. Seed straw and biological yields were determined per plot and then total seed, straw and biological yields/ fad,were calculated.

\section{Statistical analyses}

All the collected data were analyzed statically according to Steel et al., $(1997)^{[15]}$. Combined analysis of the two seasons was computed. Differences between means were compared by using Dun can multiple range test (Gomez and Gomez ,1984) $)^{[16]}$

\section{Results and Discussion}

\subsection{Number of Nodules / Plant and Dry Weight of Nodules (Mg / Plants)}

Number of nodules / plant and dry weight of nodules (mg/plants), at 50 and 75 DAS as affected by gamma irradiation doses, micronutrient application methods and micronutrient mixtures are presented in Table 1.

\subsubsection{Gamma irradiation effect}

Generally, number of nodules/plant and dry weight of nodules plant of gamma irradiation plants recorded 50 and 75 DAS in both seasons and their combined analysis, surpassed those of unirradiated plants. The most effective irradiation dose in increasing number and dry weight of nodules/plant was 30 Gy, followed by $15 \mathrm{~Gy}$, while the highest irradiation dose (60 Gy) ranked last.

\subsubsection{Micronutrient application methods effect}

Nodulation parameters of faba bean plants (Table 1) expressed as number of nodules / plant and dry weight of nodules (mg/ plant) were the highest when the micronutrient application was via spraying method, while nodulation parameters were the lowest when the micronutrient application methods was via pre-sowing seed coating. Micronutrient application via seed soaking has a moderate efficiency on nodulation parameters. 
The previous results were in conformity with those of both seasons and their combined data. Foliar application with micronutrients could be more effective than soil application because it overcomes deficiency problem in the soil (Modaihsh, 1997) ${ }^{[17]}$

\subsubsection{Micronutrient mixtures effect}

In general, application micronutrient mixtures in comparison with the control treatment resulted in more number of nodules/ plant and heavier weight of nodules (mg/ plant) in both seasons and their boold analysis. Inter the two micronutrient mixtures, the mixture of $\mathrm{Fe}+\mathrm{Zn}+\mathrm{Mn}$ compared with the mixture of $\mathrm{Fe}+\mathrm{Zn}+\mathrm{Mn}+$ Mo caused significant increments in both number and dry weight of nodules/plant recorded at 50 and 75 DAS in both seasons and the combined analysis . Based on the combined data, number of nodules /plant were 39.38 vs 33.55 and 45.60 vs 42.0 at 50 and 75 DAS, moreover, dry of nodules (mg/plant) recoded $0.41 \mathrm{vs}$ 0.35 and 0.66 vs 0.53 at 50 and 75 DAS.

\subsubsection{Interaction effect}

It is obvious from Table 1 that the dualist interactions between the three main factors under study were significant in both seasons and the combined analysis; it was also explicit that the interaction effects on both number and dry weight of nodules/plant tented to be in conformity with the main effects; consequently, interaction tables were not discussed.

\subsection{Leaf Area (Cm2/Plant) and Leaf Area Index}

Effect of gamma irradiation, micronutrient application methods and micronutrient mixture on faba bean leaf area $\left(\mathrm{cm}^{2} /\right.$ plant $)$ and leaf area index (LAI) recorded 75 DAS are shown in Table 2.

\subsubsection{Gamma irradiation effect}

Leaf area $\left(\mathrm{cm}^{2} /\right.$ plant $)$ and leaf area index of faba bean plants measured 75 DAS were larger when any gamma irradiation dose was used as pre-sowing treatment, compared with the unirradiated treatment. Based on combined data, the largest leaf area $\left(624.39 \mathrm{~cm}^{2} / \mathrm{plant}\right)$ and leaf area index $(0.69)$ could be attained when gamma irradiation dose of 30 Gy was used followed by using 15 Gy. Moussa $(2006)^{[18]}$ reported that low doses of gamma radiation may increase the enzymatic activation and awakening of the young embryo, which results in stimulating the rate of cell division and affects vegetative growth Abou El-Yazeid (2011) ${ }^{[3]}$ indicated that presowing irradiation with $30 \mathrm{~Gy}$, produced the higest value of leaf area.

\subsubsection{Micronutrient application methods effect}

Various micronutrient application methods caused marked and significant effect on faba bean vegetative growth expresses as leaf area $\left(\mathrm{cm}^{2} /\right.$ plant) and leaf area index recorded at 75 DAS. The most favorable micronutrient application method was foliar application, followed by soaking, while coating ranked last, these views were avouched in both seasons and their combined analysis. These results are in agreement with those of Salem and El-Gizawy (2012) $)^{[19]}$, who found that foliar application method, gave the highest value of leaf area compared to soaking and coating methods.

\subsubsection{Micronutrient mixtures effect}

The two micronutrient mixtures i.e. $\mathrm{Fe}+\mathrm{Zn}+\mathrm{Mn} ; \mathrm{Fe}+\mathrm{Zn}+\mathrm{Mn}+$ Mo enhanced significantly faba bean leaf area/ plant and LAI (sample aged 75 days)compared to the control (unfertilized plants ) in both seasons and the combined analysis. The most outgrow of faba bean plants in both leaf area / plant and leaf area index caused due to the application of $(\mathrm{Fe}+\mathrm{Zn}+\mathrm{Mn})$ micronutrient mixture. Salem and El-Gizawy $(2012)^{[19]}$ concluded that, micronutrient fertilization using $\mathrm{Fe}+\mathrm{Zn}+\mathrm{Mn}$ was the most effective treatment in increasing maize leaf area/ plant.

\subsubsection{Interaction effect}

As shown in both seasons and the combined analysis (Table 2), The interaction effect (gamma irradiation dose $\times$ micronutrient application methods, gamma irradiation doses $\times$ micronutrient mixtures, micronutrient application methods $\times$ micronutrient mixtures) on both leaf area $\left(\mathrm{cm}^{2} / \mathrm{plant}\right)$ and leaf area index were significant. But, no additional information could be obtained other than the main effects. Therefore, interaction tables were neither shown nor discussed.

\subsection{Chlorophyll A, Chlorophyll B and Carotene}

Data in (Table 3) demonstrate the effect of gamma irradiation doses, micronutrient application methods and micronutrient mixtures on faba bean leaf content of chlorophyll A, B and carotene at75 DAS. 


\subsubsection{Gamma irradiation effect}

Faba bean leaves content of photosynthetic pigments i.e. chlorophyll A, chlorophyll B and carotene increased gradually with raising gamma irradiation dose up to $30 \mathrm{~Gy}$, additional increase in gamma irradiation dose up to 60 Gy was of no avail and accompanied by significant reduce in faba bean leaves content of photosynthetic pigments. It is worth to note that irradiation treatments surpassed the un - irradiated plants respecting leaves content of photosynthetic pigments. The abovementioned results were inferred in both seasons and the combined analysis. Similarly, Hegazi and Hamideldin $(2010)^{[20]}$ postulated that all photosynthetic pigments content were significantly increased as a result of gamma irradiation treatment.

\subsubsection{Micronutrient application methods effect}

Micronutrient application methods affected significantly leaves content of photosynthetic pigments in both seasons and the combined analysis. Foliar application of micronutrients resulted in the highest leaves content of chlorophyll A, chlorophyll B and carotene compared with either seed coating or seed soaking. Salem and El-Gizawy (2012) ${ }^{[19]}$ stated that foliar spray with ( $\mathrm{Fe}+\mathrm{Zn}+\mathrm{Mn}$ ) was the most efficient method in increasing chlorophyll A, chlorophyll B and carotene concentrations in maize leaves comparing with soaking and coating methods.

\subsubsection{Micronutrient mixtures effect}

Response of faba bean leaves content from each of chlorophyll A, chlorophyll B and carotene to micronutrient mixtures was significant. Appliance of either $(\mathrm{Fe}+\mathrm{Zn}+\mathrm{Mn})$ or $(\mathrm{Fe}+\mathrm{Zn}+\mathrm{Mn}+\mathrm{Mo})$ micronutrient mixture outstripped the control treatment (underutilization).The highest leaves concentration of photosynthetic pigments could obtained by supplying the micronutrient mixture of $(\mathrm{Fe}+\mathrm{Zn}+\mathrm{Mn})$, followed by supplying the micronutrient mixture of $(\mathrm{Fe}+\mathrm{Zn}+\mathrm{Mn}+\mathrm{Mo})$. All the above views were ascertained in both seasons and the combined analysis. Chlorophyll $\mathrm{A}$ and $\mathrm{B}$ has the higher values with supplying $(\mathrm{Fe}+\mathrm{Zn}+\mathrm{Mn})$ mixture nutrient than other Zn, Mn and Fe treatments, these views were expressed by Salem and El-Gizawy $(2012)^{[19]}$

\subsection{Plant Height (cm), Number of Branches and Number of Pods/Plant}

Table 4 shows faba bean plant height $(\mathrm{cm})$, number of branches, and number of pods/ plant at harvest in the two seasons and their combined as affected by gamma irradiation doses, micronutrient application methods and micronutrient mixtures.

\subsubsection{Gamma irradiation effect}

Results in Table 2 revealed significant differences in both seasons and their combined as well, regarding plant height, number of branches and number of pods/ plant. Data of both seasons and the combined analysis indicated that pre-sowing seed irradiation with 15,30 and 60 Gy produced tall plants with more branches and pods number/ plant compared with the un-irradiated plants. The most favorable gamma irradiation dose was $30 \mathrm{~Gy}$, surpassing that dose up to $60 \mathrm{~Gy}$ was accompanied by significant decrease, that influence was affirmant in each of plant height, number of branches and pods/ plant in both seasons and the combined data.

In the literature, several worker doucemented the importance of gamma irradiation in meliorting plant height, number of branches and number of pods/ plant (Farag , 1996 ${ }^{[21]}$; Gaberet al. ,2000 ${ }^{[22]}$; Tamaset al. $2005^{[23]}$; Norfadzrinet al., 2007 $7^{[24]}$; Dubeyet al. , 2007 $7^{[25]}$; farag and El-Khawaga 2013 ${ }^{[26]}$; Farag and Abd ElHameed, $2013^{[27]}$ ).

\subsubsection{Micronutrient application methods effect}

According to the combined data, micronutrient application via spraying methods produced the tallest plants $(105.7 \mathrm{~cm})$, the highest number of branches / plant (3.51) and the highest number of pods/ plant (12.92), micronutrient application via seed soaking ranked second and recorded 102.0, 3.26 and 11.91 for plant height, number of branches/ plant and number of pods/ plant, respectively, further, micronutrient application throw seed coating ranked last. Salem and El-Gizawy $(2012)^{[19]}$ found that, the foliar spraying gave the highest values of plant height than other application methods (seed soaking and coating).

\subsubsection{Micronutrient mixtures effect}

Comparing application of micronutrient mixtures with the control, revealed that fertilized plants outrankrd unfertilized plants in each plant height, number of branches and number of pods/plant, that was valid in both seasons and their combined data. Over and above, supplies of $(\mathrm{Fe}+\mathrm{Zn}+\mathrm{Mn})$ as micronutrient mixture was more affective than supplies of $(\mathrm{Fe}+\mathrm{Zn}+\mathrm{Mn}+\mathrm{Mo})$ as micronutrient mixture, consequently produced taller plants with more number of branches and pods/plant. Data reported by Salem and El- Gizawy (2012) ${ }^{[19]}$ on maize showed that micronutrients fertilization using $\mathrm{Fe}+\mathrm{Zn}+\mathrm{Mn}$ treatment was the most effective treatment regarding plant height. 


\subsubsection{Interaction effect}

Plant height was significantly affected by the dualist interactions between gamma irradiation doses, micronutrient application methods and micronutrient mixtures that was true in first seasons and the combined analysis. It is worth to note that the interaction effects on plant height was in conformity with the main effects, consequently interaction tables were not shown and were not discussed. Based on combined analysis, interaction effect were insignificant on each of number of branches /plant and number of pods/plant.

\subsection{Number of Seeds/Pod, Seed Weight (g/Plant) and 100 Seed Weight (g)}

The effect of gamma irradiation doses, micronutrient application methods and micronutrient mixtures on each of number of seeds /pod, seed weight/plant and 100 -seed weight $(\mathrm{g})$ is shown in Table (5).

\subsubsection{Gamma irradiation effect}

As per data of number of seeds/pod in both seasons and their combined analysis, it was obvious that pre-sowing seed irradiation with doses of 15,30 and $60 \mathrm{~Gy}$ was ineffectual on number of seed/ pod, but out of regard for gamma irradiation treatments effect on both seed weight / plant and 100 seed weight, all pre-sowing seed irradiation treatments were superior over the control(un-irradiated plants). The highest seed weight/plant as well as 100- seed weight could be obtained due to pre-sowing seed irradiation with the dose of $30 \mathrm{~Gy}$, that was true in both seasons and the combined analysis. The superiority of seed weight / plant due to pre-sowing seed irradiation with the dose of $30 \mathrm{~Gy}$, was expected, because of its effective impact on each of plant height, number of branches / plant and number of pods /plant, therefore increment in seed weight/plant was obtained.

The positive and stimulatory effects on seed weight/plant was conformed with the finding of Sundaravadiveluet al., $(2006)^{[28]}$; Sujaya - Das et al. (2007) ${ }^{[29]}$; Khan et al.(2010) $)^{[30]}$; Rahm Din et al. ,(2010) ${ }^{[31]}$; Singh and $\operatorname{Datta}(2010)^{[32]}$; as well as Farag and Abed El - Hameed (2013) ${ }^{[27]}$.

\subsubsection{Micrinutrient application methods effect}

Number of seeds /pod in both seasons and their combined analysis exhibited insensitive response to micronutrient application methods. Both seed weight /plant and 100 -seed weight had significantly affected by varying micronutrient application methods, foliar spraying resulted in the best seed weight / plant as well as the heaviest 100 -seed weight, whlist coating application method resulted in the lowest seed weight/ plant and 100 seed weight in both seasons and the combined analysis. Micronutrient application via seed soaking had a moderate efficiency on both seed weight / plant and 100- seed weight. The previous results were in conformity with those of number of nodules/ plant, dry weight of nodules / plant (Table 1); leaf area / plant, leaf area index ( Table 2); chlorophyll A,B and carotene content ( Table 3); Plant height, number of branches / plant and number of pods/ plant ( $\underline{\text { Table } 4})$.

\subsubsection{Micronutrient mixtures effect}

Generally, application of micronutrient mixture comparing to the control treatment, resulted in heavier seed weight /plant as well as heavier 100- seed weight in both seasons and their boold analysis. Inter the twomicronutrient mixtures, the mixture of $\mathrm{Fe}+\mathrm{Zn}+\mathrm{Mn}$ compared with the mixture of $\mathrm{Fe}+\mathrm{Zn}+\mathrm{Mn}+\mathrm{Mo}$ caused significant increments in both seed weight /plant and 100-seed weight, in both seasons and the combined analysis. Micronutrient mixtures effect number of seeds/pod was of no use. Superiority of $\mathrm{Fe}+\mathrm{Zn}+\mathrm{Mn}$ micronutrient mixture was also obvious in most of growth traits as well as yield component studied. The increase of yield component due to micronutrient application might be due to their positive effect of micronutrients on seed yield component were reported by Abdoet al., $(2002)^{[33]}$; Farzanianet al., $(2010)^{[34]}$; Babaeianet al., (2010) ${ }^{[35]}$; Ebrahimian and Bybordi (2011) ${ }^{[36]}$ and Omar and Abd-El- Hameed $(2012)^{[37]}$.

\subsubsection{Interaction effect}

Regarding to seed weight / plant and 100- seed weight, it is obvious from Table 5 that the dualist interactions between the three main factors studied, were significant in both seasons and their combined analysis, it was also explicit that the interaction effects on both seed weight / plant and 100 -seed weight, tended to be in conformity with the main effects, So interaction tables were not shown and were not discussed. Number of seeds /pod was significantly affected by the three dual interactions.

\subsection{Seed, Straw and Biological Yield/Fad}

Results of seed yield (ardab/fad.), straw yield (ton/ fad.) and biological yield (ton/ fad.) as influenced by gamma irradiation doses, micronutrient application methods and micronutrient mixtures are presented in Table (6). 


\subsubsection{Gamma irradiation effect}

Pre-sowing seed irradiation with 15,30 or 60 Gy yielded more seeds, straw and biological yields compared with yields produced from unirradiated plants, that was valid in both seasons and the combined analysis . The highest seed, straw and biological yields were obtained due to the irradiation dose of $30 \mathrm{~Gy}$, raising gamma irradiation dose up to $60 \mathrm{~Gy}$ decreased that yields. These results were expected since the efficacious role of gamma irradiation with $30 \mathrm{~Gy}$ was obvious in most growth traits as well as most yield components studied. In the literature, several workers documented the importance of gamma irradiation in meliorating seed, straw and biological yields (Farag ,1996 $6^{[21]}$; Gaberet al. $2000^{[22]}$; Tamaset al., 2005 $5^{[23]}$; Khan et

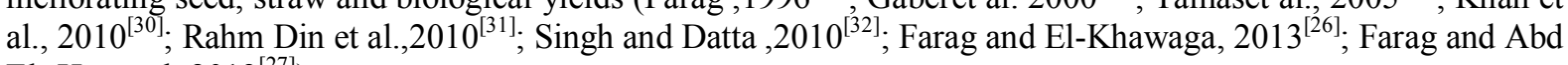
El- Hameed, 2013 ${ }^{[27]}$ )

\subsubsection{Micronutrient application methods effect}

It is evident from Table 6 that, the three-micronutrient application methods under study reflected significant effects on seed, straw and biological yields; the ascending order was spraying >soaking >coating in the two seasons and their combined analysis. Supereminence of foliar spraying application method over both soaking and coating application methods was obvious not only in seed, straw and biological yields, but also in each of number of nodules /plant, dry weight of nodules / plant, plant height, number of branches/ plant, number of pods /plant, seed weight/ plant and 100 -seed weight. Similar views were expressed by Modaihsh, $1997^{[17]}$; Hegazi and Hamideldin ,2010 $0^{[20]}$ and Salem and El Gizawy 2012 ${ }^{[19]}$.

\subsubsection{Micronutrient mixtures effect}

Application of micronutrient mixtures in general seed, straw and biological yields comparied with the control, that was valid in both seasons and the combined analysis. Furthermore, supplies of $(\mathrm{Fe}+\mathrm{Zn}+\mathrm{Mn})$ as micronutrient mixture was more efficient than supplies of $(\mathrm{Fe}+\mathrm{Zn}+\mathrm{Mn}+\mathrm{Mo})$ as micronutrient mixture, consequently produced more seed, straw and biological yields. It is worth to mention that supplies of the micronutrient mixture $(\mathrm{Fe}+\mathrm{Zn}+\mathrm{Mn})$ was superior also in most growth and yield attributes studied. The increase of yield components due to micronutrients application might be due to their positive effects on assimilates translocation, activation of photosynthetic enzymes, chlorophyll formation and improvement of plant growth. The meliorating effect of micronutrient mixture was also reported by Abdoet al., (2002) ${ }^{[33]}$; Farzanianet al., $(2010)^{[34]}$; Babaeianet al., (2010) ${ }^{[35]}$; Babaeianet al., (2011) ${ }^{[38]}$ Ebrahimian and Bybordi $(2011)^{[36]}$ and Omar and Abd El- Hameed (2012) ${ }^{[37]}$.

\subsubsection{Interaction effect}

Seed, straw and biological yields were significantly affected by the dualist interaction between gamma irradiation doses, micronutrient application methods and micronutrient mixtures that was true in both seasons and the combined analysis. It is worth to note that the interaction effects on seed, straw and biological yields were in conformity with the main effects, using gamma irradiation dose of 30 Gy with foliar spraying as micronutrient application methods produced the highest seed, straw and biological yields, while the lowest yields were obtained due to pre-sowing gamma irradiation dose of $60 \mathrm{~Gy}$ in combination with seed coating as micronutrient application methods.

\section{Figures and Tables}

Table (1) Effect of gamma irradiation, micronutrient application methods and micronutrient mixtures on number and dry weight of nodules/plant of faba bean at 50 and 75 DAS* in two seasons and their combined

\begin{tabular}{|c|c|c|c|c|c|c|c|c|c|c|c|c|}
\hline \multirow{3}{*}{$\begin{array}{c}\text { Main } \\
\text { effects } \\
\text { and } \\
\text { interact } \\
\text { ion } \\
\end{array}$} & \multicolumn{6}{|c|}{ Number of nodules / plant } & \multicolumn{6}{|c|}{ Dry weight of nodules(mg /plant) } \\
\hline & \multicolumn{3}{|c|}{50 DAS* } & \multicolumn{3}{|c|}{75 DAS* } & \multicolumn{3}{|c|}{50 DAS* } & \multicolumn{3}{|c|}{75 DAS* } \\
\hline & $\begin{array}{c}2010 / \\
11 \\
\end{array}$ & $2011 / 12$ & Comb. & $\begin{array}{c}2010 / \\
11 \\
\end{array}$ & $\begin{array}{c}2011 / 1 \\
2 \\
\end{array}$ & Comb. & $\begin{array}{c}2010 / \\
11 \\
\end{array}$ & $\begin{array}{c}2011 / 1 \\
2 \\
\end{array}$ & Comb & $\begin{array}{c}2010 / 1 \\
1 \\
\end{array}$ & $\begin{array}{c}2011 / \\
12 \\
\end{array}$ & Comb. \\
\hline \multicolumn{13}{|c|}{ A- Gamma irradiation (GY) } \\
\hline Zero & $\begin{array}{c}28.02 \\
\mathrm{~d}\end{array}$ & $27.21 \mathrm{~d}$ & $27.62 d$ & $32.30 \mathrm{~d}$ & $30.76 \mathrm{~d}$ & $31.53 \mathrm{~d}$ & $0.25 \mathrm{~d}$ & $0.27 \mathrm{~d}$ & $0.26 \mathrm{~d}$ & $0.37 \mathrm{~d}$ & $0.43 \mathrm{~d}$ & $0.40 \mathrm{~d}$ \\
\hline 15 & $\begin{array}{c}38.83 \\
\mathrm{~b}\end{array}$ & $33.32 b$ & $36.08 b$ & $40.76 \mathrm{~b}$ & $40.85 b$ & $40.81 b$ & $0.35 \mathrm{~b}$ & $0.38 \mathrm{~b}$ & $0.37 \mathrm{~b}$ & $0.51 \mathrm{~b}$ & $0.64 \mathrm{~b}$ & $0.58 b$ \\
\hline 30 & $\begin{array}{c}41.12 \\
\mathrm{a}\end{array}$ & $37.63 \mathrm{a}$ & $39.38 \mathrm{a}$ & $47.91 \mathrm{a}$ & $43.28 \mathrm{a}$ & $45.60 \mathrm{a}$ & $0.40 \mathrm{a}$ & $0.43 \mathrm{a}$ & $0.42 \mathrm{a}$ & $0.59 \mathrm{a}$ & $0.73 \mathrm{a}$ & $0.66 \mathrm{a}$ \\
\hline 60 & $\begin{array}{c}30.58 \\
\mathrm{c}\end{array}$ & $31.12 \mathrm{c}$ & $30.85 \mathrm{c}$ & $40.51 \mathrm{c}$ & $38.89 \mathrm{c}$ & $39.70 \mathrm{c}$ & $0.27 \mathrm{c}$ & $0.32 \mathrm{c}$ & $0.30 \mathrm{c}$ & $0.42 \mathrm{c}$ & $0.51 \mathrm{c}$ & $0.47 \mathrm{c}$ \\
\hline F-test & * & * & * & * & * & * & * & * & * & * & * & * \\
\hline \multicolumn{13}{|c|}{ B- Micronutrient application methods } \\
\hline Coating & 28.62 & $37.21 \mathrm{c}$ & $31.27 \mathrm{c}$ & $40.69 \mathrm{c}$ & $35.98 \mathrm{c}$ & $39.41 \mathrm{c}$ & $0.23 \mathrm{c}$ & $0.23 \mathrm{c}$ & $0.23 \mathrm{c}$ & $0.37 \mathrm{c}$ & $0.51 \mathrm{c}$ & $0.44 \mathrm{c}$ \\
\hline
\end{tabular}


Importance of Gamma Irradiation, Micronutrient Mixtures and Their Application Methods

\begin{tabular}{|c|c|c|c|c|c|c|c|c|c|c|c|c|}
\hline & $\mathrm{c}$ & & & & & & & & & & & \\
\hline $\begin{array}{c}\text { Soakin } \\
\mathrm{g}\end{array}$ & $\begin{array}{c}35.87 \\
b\end{array}$ & $26.66 \mathrm{~b}$ & $32.92 b$ & $45.39 b$ & $39.15 b$ & $43.17 b$ & $0.31 b$ & $0.39 b$ & $0.35 b$ & $0.46 \mathrm{~b}$ & $0.55 b$ & $0.51 \mathrm{~b}$ \\
\hline $\begin{array}{c}\text { Sprayin } \\
\text { g }\end{array}$ & $\begin{array}{c}39.43 \\
\mathrm{a}\end{array}$ & $33.08 \mathrm{a}$ & $36.26 \mathrm{a}$ & $45.50 \mathrm{a}$ & $40.88 \mathrm{a}$ & $44.73 \mathrm{a}$ & $0.41 \mathrm{a}$ & $0.43 \mathrm{a}$ & $0.42 \mathrm{a}$ & $0.58 \mathrm{a}$ & $0.68 \mathrm{a}$ & $0.63 \mathrm{a}$ \\
\hline F-test & $*$ & $*$ & $*$ & $*$ & $*$ & $*$ & $*$ & $*$ & $*$ & $*$ & $*$ & $*$ \\
\hline \multicolumn{13}{|c|}{ C- Micronutrient mixtures } \\
\hline Control & $\begin{array}{c}27.99 \\
c\end{array}$ & $27.00 \mathrm{c}$ & $27.50 \mathrm{c}$ & $40.52 \mathrm{c}$ & $38.89 \mathrm{c}$ & $39.71 \mathrm{c}$ & $0.23 \mathrm{c}$ & $0.25 \mathrm{c}$ & $0.24 \mathrm{c}$ & $0.34 \mathrm{c}$ & $0.42 \mathrm{c}$ & $0.37 \mathrm{c}$ \\
\hline $\begin{array}{c}\mathrm{Fe}+\mathrm{Zn} \\
+\mathrm{Mn}\end{array}$ & $\begin{array}{c}41.12 \\
\mathrm{a}\end{array}$ & $37.63 \mathrm{a}$ & $39.38 \mathrm{a}$ & $47.91 \mathrm{a}$ & $43.28 \mathrm{a}$ & $45.60 \mathrm{a}$ & $0.39 \mathrm{a}$ & $0.43 \mathrm{a}$ & $0.41 \mathrm{a}$ & $0.59 \mathrm{a}$ & $0.75 \mathrm{a}$ & $0.66 \mathrm{a}$ \\
\hline $\begin{array}{c}\mathrm{Fe}+\mathrm{Zn} \\
+\mathrm{Mn}+ \\
\mathrm{Mo}\end{array}$ & $\begin{array}{c}34.77 \\
b\end{array}$ & $32.32 b$ & $33.55 b$ & $43.15 b$ & $40.85 b$ & $42.00 \mathrm{~b}$ & $0.33 b$ & $0.37 \mathrm{~b}$ & $0.35 b$ & $0.48 b$ & $0.57 b$ & $0.53 b$ \\
\hline F-test & $*$ & $*$ & $*$ & $*$ & $*$ & $*$ & $*$ & $*$ & $*$ & $*$ & $*$ & $*$ \\
\hline \multicolumn{13}{|c|}{ Interaction } \\
\hline $\mathrm{AxB}$ & $*$ & $*$ & $*$ & $*$ & $*$ & $*$ & $*$ & $*$ & $*$ & $*$ & $*$ & $*$ \\
\hline $\mathrm{AxC}$ & $*$ & $*$ & $*$ & $*$ & $*$ & $*$ & $*$ & $*$ & $*$ & $*$ & $*$ & $*$ \\
\hline $\mathrm{BxC}$ & $*$ & * & * & $*$ & * & $*$ & $*$ & $*$ & $*$ & $*$ & $*$ & * \\
\hline
\end{tabular}

$\mathrm{DAS}^{*}=$ Days after sowing Comb. $=$ combined analysis

Table (2) Effect of gamma irradiation, micronutrient application methods and micronutrient mixtures on leaf area (cm2/plant) and Leaf area index of faba bean at 75 DAS* in two seasons and their combined

\begin{tabular}{|c|c|c|c|c|c|c|}
\hline \multirow{2}{*}{$\begin{array}{l}\text { Main effects and } \\
\text { interaction }\end{array}$} & \multicolumn{3}{|c|}{ Leaf area $\left(\mathrm{cm}^{2} /\right.$ plant $) 75$ DAS } & \multicolumn{3}{|c|}{ Leaf area index 75 DAS } \\
\hline & $2010 / 2011$ & $2011 / 2012$ & Comb & $2010 / 2011$ & $2011 / 2012$ & Comb \\
\hline \multicolumn{7}{|c|}{ A-Gamma irradiation (GY) } \\
\hline Zero & $532.28 \mathrm{~d}$ & $574.72 \mathrm{~d}$ & $553.50 \mathrm{~d}$ & $0.59 \mathrm{~d}$ & $0.64 d$ & $0.62 \mathrm{~d}$ \\
\hline 15 & $575.15 b$ & $619.67 \mathrm{~b}$ & $597.41 \mathrm{~b}$ & $0.64 b$ & $0.69 \mathrm{~b}$ & $0.66 \mathrm{~b}$ \\
\hline 30 & $598.54 a$ & $650.24 \mathrm{a}$ & $624.39 \mathrm{a}$ & $0.67 \mathrm{a}$ & $0.72 \mathrm{a}$ & $0.69 \mathrm{a}$ \\
\hline 60 & $550.2 \mathrm{c}$ & $599.89 \mathrm{c}$ & $575.05 \mathrm{c}$ & $0.61 \mathrm{c}$ & $0.67 \mathrm{c}$ & $0.64 \mathrm{c}$ \\
\hline F-test & $*$ & $*$ & $*$ & $*$ & $*$ & $*$ \\
\hline \multicolumn{7}{|c|}{ B-Micronutrient application methods } \\
\hline Coating & $477.62 \mathrm{c}$ & $526.16 \mathrm{c}$ & $501.89 \mathrm{c}$ & $0.53 \mathrm{c}$ & $0.58 \mathrm{c}$ & $0.56 \mathrm{c}$ \\
\hline Soaking & $565.84 \mathrm{~b}$ & $586.88 \mathrm{~b}$ & $576.36 \mathrm{~b}$ & $0.63 \mathrm{~b}$ & $0.65 \mathrm{~b}$ & $0.64 \mathrm{~b}$ \\
\hline Spraying & $632.08 \mathrm{a}$ & $686.44 a$ & $659.26 \mathrm{a}$ & $0.70 \mathrm{a}$ & $0.76 \mathrm{a}$ & $0.73 a$ \\
\hline F-test & $*$ & $*$ & $*$ & $*$ & $*$ & $*$ \\
\hline \multicolumn{7}{|c|}{ C-Micronutrient mixtures } \\
\hline Control & $530.59 \mathrm{c}$ & $546.19 \mathrm{c}$ & $538.39 \mathrm{c}$ & $0.59 \mathrm{c}$ & $\overline{0.61 \mathrm{c}}$ & $0.60 \mathrm{c}$ \\
\hline $\mathrm{Fe}+\mathrm{Zn}+\mathrm{Mn}$ & $587.82 \mathrm{a}$ & $603.47 \mathrm{a}$ & $595.65 \mathrm{a}$ & $0.65 \mathrm{a}$ & $0.67 \mathrm{a}$ & $0.66 \mathrm{a}$ \\
\hline $\mathrm{Fe}+\mathrm{Zn}+\mathrm{Mn}+\mathrm{Mo}$ & $557.23 b$ & $575.98 \mathrm{~b}$ & $566.61 \mathrm{~b}$ & $0.62 b$ & $0.64 \mathrm{~b}$ & $0.63 \mathrm{~b}$ \\
\hline F-test & $*$ & $*$ & $*$ & $*$ & $*$ & $*$ \\
\hline \multicolumn{7}{|l|}{ Interaction } \\
\hline $\mathrm{AxB}$ & $*$ & $*$ & $*$ & $*$ & $*$ & $*$ \\
\hline $\mathrm{AxC}$ & $*$ & $*$ & $*$ & $*$ & $*$ & $*$ \\
\hline $\mathrm{BxC}$ & $*$ & $*$ & $*$ & $*$ & $*$ & $*$ \\
\hline
\end{tabular}

DAS* = Days after sowing

Table (3): Effect of gamma irradiation, micronutrient application methods and micronutrient mixtures on faba bean leaves content of Chlorophyll A, Chlorophyll B and Carotene (mg/g fresh weight) at 75 DAS* in two

\begin{tabular}{|c|c|c|c|c|c|c|c|c|c|}
\hline \multirow{2}{*}{$\begin{array}{l}\text { Main effects } \\
\text { and interaction }\end{array}$} & \multicolumn{3}{|c|}{ Chlorophyll A } & \multicolumn{3}{|c|}{ Chlorophyll B } & \multicolumn{3}{|c|}{ Carotene } \\
\hline & $2010 / 2011$ & $2011 / 2012$ & Comb & $2010 / 2011$ & $2011 / 2012$ & Comb & $2010 / 2011$ & $\begin{array}{c}2011 / 20 \\
12 \\
\end{array}$ & Comb \\
\hline \multicolumn{10}{|c|}{ A-Gamma irradiation (GY) } \\
\hline Zero & $8.33 \mathrm{~d}$ & $8.33 \mathrm{~d}$ & $8.33 \mathrm{~d}$ & $5.38 \mathrm{~d}$ & $5.67 \mathrm{~d}$ & $5.53 \mathrm{~d}$ & $13.71 \mathrm{~d}$ & $14 \mathrm{~d}$ & $13.86 \mathrm{~d}$ \\
\hline 15 & $9.37 \mathrm{~b}$ & $9.37 \mathrm{~b}$ & $9.37 \mathrm{~b}$ & $5.83 \mathrm{~b}$ & $6.21 \mathrm{~b}$ & $6.02 \mathrm{~b}$ & $15.2 \mathrm{~b}$ & $15.58 \mathrm{~b}$ & $15.39 \mathrm{~b}$ \\
\hline 30 & $9.73 a$ & $9.73 a$ & $9.73 a$ & $6.37 \mathrm{a}$ & $6.69 a$ & $6.53 a$ & $16.1 \mathrm{a}$ & $16.42 \mathrm{a}$ & $16.26 \mathrm{a}$ \\
\hline 60 & $9.14 \mathrm{c}$ & $9.14 \mathrm{c}$ & $9.14 \mathrm{c}$ & $5.75 \mathrm{c}$ & $5.87 \mathrm{c}$ & $5.81 \mathrm{c}$ & $14.89 \mathrm{c}$ & $15.01 \mathrm{c}$ & $14.95 \mathrm{c}$ \\
\hline F-test & $*$ & * & $*$ & $*$ & $*$ & $*$ & $*$ & * & * \\
\hline \multicolumn{10}{|c|}{ B-Micronutrient application methods } \\
\hline Coating & $8.77 \mathrm{c}$ & $8.77 \mathrm{c}$ & $8.77 \mathrm{c}$ & $5.39 \mathrm{c}$ & $5.66 \mathrm{c}$ & $5.53 \mathrm{c}$ & $14.16 \mathrm{c}$ & $14.43 \mathrm{c}$ & $14.30 \mathrm{c}$ \\
\hline Soaking & $8.96 b$ & $8.96 b$ & $8.96 \mathrm{~b}$ & $5.82 \mathrm{~b}$ & $6.11 \mathrm{~b}$ & $5.97 \mathrm{~b}$ & $14.78 \mathrm{~b}$ & $15.07 \mathrm{~b}$ & $14.93 \mathrm{~b}$ \\
\hline Spraying & $9.69 \mathrm{a}$ & $9.69 \mathrm{a}$ & $9.69 \mathrm{a}$ & $6.28 \mathrm{a}$ & $6.57 \mathrm{a}$ & $6.43 \mathrm{a}$ & $15.97 \mathrm{a}$ & $16.26 \mathrm{a}$ & $16.12 \mathrm{a}$ \\
\hline
\end{tabular}




\begin{tabular}{|c|c|c|c|c|c|c|c|c|c|}
\hline F-test & $*$ & $*$ & $*$ & $*$ & $*$ & $*$ & $*$ & $*$ & $*$ \\
\hline \multicolumn{10}{|c|}{ C-Micronutrient mixtures } \\
\hline Control & $8.61 \mathrm{c}$ & $8.61 \mathrm{c}$ & $8.61 \mathrm{c}$ & $5.47 \mathrm{c}$ & $5.73 \mathrm{c}$ & $5.60 \mathrm{c}$ & $14.08 \mathrm{c}$ & $14.34 \mathrm{c}$ & $14.21 \mathrm{c}$ \\
\hline $\mathrm{Fe}+\mathrm{Zn}+\mathrm{Mn}$ & $9.32 \mathrm{a}$ & $9.32 \mathrm{a}$ & $9.32 \mathrm{a}$ & $6.18 \mathrm{a}$ & $6.49 a$ & $6.34 \mathrm{a}$ & $15.5 \mathrm{a}$ & $15.81 \mathrm{a}$ & $15.66 \mathrm{a}$ \\
\hline $\mathrm{Fe}+\mathrm{Zn}+\mathrm{Mn}+\mathrm{Mo}$ & $8.89 \mathrm{~b}$ & $8.89 \mathrm{~b}$ & $8.89 \mathrm{~b}$ & $5.83 \mathrm{~b}$ & $6.11 \mathrm{~b}$ & $5.97 \mathrm{~b}$ & $14.72 \mathrm{~b}$ & $15.0 \mathrm{~b}$ & $14.86 \mathrm{~b}$ \\
\hline F-test & $*$ & $*$ & $*$ & $*$ & $*$ & $*$ & $*$ & $*$ & $*$ \\
\hline \multicolumn{10}{|l|}{ Interaction } \\
\hline $\mathrm{AxB}$ & $*$ & $*$ & $*$ & $*$ & $*$ & $*$ & $*$ & $*$ & $*$ \\
\hline $\mathrm{AxC}$ & $*$ & $*$ & $*$ & $*$ & $*$ & $*$ & $*$ & $*$ & $*$ \\
\hline $\mathrm{BxC}$ & $*$ & $*$ & $*$ & $*$ & $*$ & $*$ & $*$ & $*$ & $*$ \\
\hline
\end{tabular}

Table (4)Effect of gamma irradiation, micronutrient application methods and micronutrient mixtures on Plant height $(\mathrm{cm})$, number of branches and pods of faba bean in two seasons and their combined

\begin{tabular}{|c|c|c|c|c|c|c|c|c|c|}
\hline \multirow{2}{*}{$\begin{array}{l}\text { Main effects } \\
\text { and } \\
\text { interaction }\end{array}$} & \multicolumn{3}{|c|}{ Plant height $(\mathrm{cm})$} & \multicolumn{3}{|c|}{ Number of branches /plant } & \multicolumn{3}{|c|}{ Number of pods / plant } \\
\hline & $\begin{array}{c}2010 / 201 \\
1\end{array}$ & $\begin{array}{c}2011 / 201 \\
2\end{array}$ & Comb & $\begin{array}{c}2010 / 201 \\
1\end{array}$ & $\begin{array}{c}2011 / 201 \\
2\end{array}$ & Comb & $\begin{array}{c}2010 / 201 \\
1\end{array}$ & $\begin{array}{c}2011 / 201 \\
2\end{array}$ & Comb \\
\hline \multicolumn{10}{|c|}{ A- $\quad$ Gamma irradiation $(\mathrm{GY})$} \\
\hline Zero & $96.15 \mathrm{~d}$ & $97.06 \mathrm{c}$ & $96.61 \mathrm{c}$ & $2.29 \mathrm{~d}$ & $2.99 \mathrm{~d}$ & $2.64 d$ & $9.18 \mathrm{~d}$ & $9.79 \mathrm{~d}$ & $9.49 \mathrm{~d}$ \\
\hline 15 & $100.50 \mathrm{~b}$ & $106.94 a$ & $103.72 \mathrm{a}$ & $3.03 b$ & $3.18 \mathrm{~b}$ & $3 b .11 b$ & $11.36 \mathrm{~b}$ & $11.94 \mathrm{~b}$ & $11.65 b$ \\
\hline 30 & $102.93 \mathrm{a}$ & $105.03 a$ & $103.98 \mathrm{a}$ & $3.44 \mathrm{a}$ & $3.73 \mathrm{a}$ & $3.59 \mathrm{a}$ & $13.55 \mathrm{a}$ & $14.22 \mathrm{a}$ & $13.89 \mathrm{a}$ \\
\hline 60 & $99.86 \mathrm{c}$ & $103.01 \mathrm{~b}$ & $101.44 b$ & $2.62 \mathrm{c}$ & $3.45 \mathrm{c}$ & $3.04 \mathrm{c}$ & $11.18 \mathrm{c}$ & $11.84 \mathrm{c}$ & $11.51 \mathrm{c}$ \\
\hline F-test & * & $*$ & $*$ & $*$ & * & * & * & $*$ & $*$ \\
\hline \multicolumn{10}{|c|}{ B-Micronutrient application methods } \\
\hline Coating & $94.59 \mathrm{c}$ & $98.61 \mathrm{c}$ & $96.60 \mathrm{c}$ & $2.89 \mathrm{c}$ & $3.07 \mathrm{c}$ & $2.98 \mathrm{c}$ & $9.67 \mathrm{c}$ & $10.43 \mathrm{c}$ & $10.05 \mathrm{c}$ \\
\hline Soaking & $100.48 b$ & $103.52 b$ & $102.00 \mathrm{~b}$ & $3.16 \mathrm{~b}$ & $3.35 b$ & $3.26 \mathrm{~b}$ & $11.55 b$ & $12.27 \mathrm{~b}$ & $11.91 \mathrm{~b}$ \\
\hline Spraying & $104.53 \mathrm{a}$ & $106.90 \mathrm{a}$ & $105.72 \mathrm{a}$ & $3.43 \mathrm{a}$ & $3.59 \mathrm{a}$ & $3.51 \mathrm{a}$ & $12.71 \mathrm{a}$ & $13.13 \mathrm{a}$ & $12.92 \mathrm{a}$ \\
\hline F-test & $*$ & $*$ & $*$ & $*$ & * & * & $*$ & $*$ & $*$ \\
\hline \multicolumn{10}{|c|}{ C-Micronutrient mixtures } \\
\hline Control & $94.25 \mathrm{c}$ & $95.27 \mathrm{c}$ & $94.76 \mathrm{c}$ & $3.05 \mathrm{c}$ & $2.96 \mathrm{c}$ & $3.01 \mathrm{c}$ & $9.48 \mathrm{c}$ & $10.36 \mathrm{c}$ & $9.92 \mathrm{c}$ \\
\hline $\mathrm{Fe}+\mathrm{Zn}+\mathrm{Mn}$ & $105.79 \mathrm{a}$ & $108.71 \mathrm{a}$ & $107.25 \mathrm{a}$ & $3.48 \mathrm{a}$ & $3.64 a$ & $3.56 \mathrm{a}$ & $13.09 \mathrm{a}$ & $13.37 \mathrm{a}$ & $13.23 \mathrm{a}$ \\
\hline $\begin{array}{l}\mathrm{Fe}+\mathrm{Zn}+\mathrm{Mn} \\
+\mathrm{Mo}\end{array}$ & $99.55 b$ & $105.03 \mathrm{~b}$ & $102.29 b$ & $3.27 \mathrm{~b}$ & $3.41 \mathrm{~b}$ & $3.34 \mathrm{~b}$ & $11.37 \mathrm{~b}$ & $12.11 \mathrm{~b}$ & $11.74 \mathrm{~b}$ \\
\hline F-test & $*$ & $*$ & $*$ & $*$ & $*$ & $*$ & $*$ & $*$ & $*$ \\
\hline \multicolumn{10}{|l|}{ Interaction } \\
\hline$\overline{A x B}$ & * & $*$ & $*$ & N.S & N.S & $\overline{\text { N.S }}$ & $\overline{\mathrm{N} . \mathrm{S}}$ & N.S & $\overline{\text { N.S }}$ \\
\hline $\mathrm{AxC}$ & $*$ & N.S & $*$ & $*$ & N.S & N.S. & $*$ & N.S & N.S \\
\hline $\mathrm{BxC}$ & $*$ & $*$ & $*$ & N.S & $*$ & N.S & $*$ & N.S & N.S \\
\hline
\end{tabular}

Table (5): Effect of gamma irradiation, micronutrient application methods and micronutrient mixtures on number of seeds/pod, seed weight (g/plant) and100-seeds weight ( $\mathrm{g}$ ) of faba bean in two seasons and their combined

\begin{tabular}{|c|c|c|c|c|c|c|c|c|c|}
\hline \multirow{2}{*}{$\begin{array}{l}\text { Main effects } \\
\text { and } \\
\text { interaction }\end{array}$} & \multicolumn{3}{|c|}{ Number of seeds /pod } & \multicolumn{3}{|c|}{ Seed weight (g/ plant) } & \multicolumn{3}{|c|}{ 100-seeds weight (g) } \\
\hline & $\begin{array}{c}2010 / 201 \\
1\end{array}$ & $2011 / 2012$ & Comb & $2010 / 2011$ & $2011 / 2012$ & Comb & $2010 / 2011$ & $2011 / 2012$ & Comb \\
\hline \multicolumn{10}{|c|}{ A-Gamma irradiation (GY) } \\
\hline Zero & 3.17 & 3.29 & 3.13 & $30.01 \mathrm{~d}$ & $32.01 \mathrm{~d}$ & $31.01 \mathrm{~d}$ & $77.05 \mathrm{~d}$ & $77.18 \mathrm{~d}$ & $77.12 \mathrm{~d}$ \\
\hline 15 & 3.33 & 3.91 & 3.62 & $36.78 \mathrm{~b}$ & $41.85 \mathrm{~b}$ & $39.32 b$ & $80.53 b$ & $81.30 \mathrm{~b}$ & $80.92 b$ \\
\hline 30 & 3.23 & 4.11 & 3.77 & $40.4 \mathrm{a}$ & $46.32 \mathrm{a}$ & $43.36 \mathrm{a}$ & $82.78 \mathrm{a}$ & $83.31 \mathrm{a}$ & $83.05 \mathrm{a}$ \\
\hline 60 & 3.27 & 3.53 & 3.40 & $34.4 \mathrm{c}$ & $38.7 \mathrm{c}$ & $36.55 \mathrm{c}$ & $78.41 \mathrm{c}$ & $79.22 \mathrm{c}$ & $78.82 \mathrm{c}$ \\
\hline F-test & N.S & N.S & N.S & $*$ & $*$ & $*$ & $*$ & $*$ & $*$ \\
\hline \multicolumn{10}{|c|}{ B-Micronutrient application methods } \\
\hline Coating & 2.33 & 3.51 & 2.92 & $30.55 \mathrm{c}$ & $35.5 \mathrm{c}$ & $33.03 \mathrm{c}$ & $\overline{777.04 \mathrm{c}}$ & $\overline{777.30 \mathrm{c}}$ & $\overline{777.17 \mathrm{c}}$ \\
\hline Soaking & 3.59 & 3.68 & 3.64 & $35.34 \mathrm{~b}$ & $38.32 b$ & $36.83 b$ & $79.02 b$ & $79.61 b$ & $79.32 b$ \\
\hline Spraying & 3.83 & 3.94 & 3.89 & $40.32 \mathrm{a}$ & $43.31 \mathrm{a}$ & $41.82 \mathrm{a}$ & $83.02 \mathrm{a}$ & $83.98 \mathrm{a}$ & $83.50 \mathrm{a}$ \\
\hline F-test & N.S & N.S & N.S & $*$ & $*$ & $*$ & $*$ & $*$ & $*$ \\
\hline \multicolumn{10}{|c|}{ C-Micronutrient mixtures } \\
\hline Control & 2.46 & 3.5 & 2.98 & $30.01 \mathrm{c}$ & $32.01 \mathrm{c}$ & $31.01 \mathrm{c}$ & $76.02 \mathrm{c}$ & $76.12 \mathrm{c}$ & $76.07 \mathrm{c}$ \\
\hline $\mathrm{Fe}+\mathrm{Zn}+\mathrm{Mn}$ & 3.85 & 3.91 & 3.88 & $39.4 \mathrm{a}$ & $45.3 \mathrm{a}$ & $42.35 \mathrm{a}$ & $82.63 a$ & $83.34 \mathrm{a}$ & $3.85 \mathrm{a}$ \\
\hline $\begin{array}{l}\mathrm{Fe}+\mathrm{Zn}+\mathrm{Mn}+ \\
\mathrm{Mo}\end{array}$ & 3.44 & 3.72 & 3.58 & $36.78 b$ & $41.85 b$ & $39.32 b$ & $80.43 b$ & $81.30 \mathrm{~b}$ & $80.87 \mathrm{~b}$ \\
\hline
\end{tabular}


Importance of Gamma Irradiation, Micronutrient Mixtures and Their Application Methods ....

\begin{tabular}{|c|c|c|c|c|c|c|c|c|c|}
\hline F-test & N.S & N.S & N.S & $*$ & $*$ & $*$ & * & $*$ & $*$ \\
\hline \multicolumn{10}{|c|}{ Interaction } \\
\hline$\overline{\mathrm{AxB}}$ & N.S & N.S & N.S & * & * & * & * & * & ** \\
\hline $\mathrm{AxC}$ & N.S & N.S & N.S & $*$ & $*$ & $*$ & $*$ & $*$ & $*$ \\
\hline $\mathrm{BxC}$ & N.S & N.S & N.S & $*$ & $*$ & $*$ & $*$ & $*$ & $*$ \\
\hline
\end{tabular}

Table (6) Effect of gamma irradiation, micronutrient application methods and micronutrient mixtures on seed, straw and biological yields /fad., of faba bean in two seasons and their combined

\begin{tabular}{|c|c|c|c|c|c|c|c|c|c|}
\hline \multirow{2}{*}{$\begin{array}{l}\text { Main effects } \\
\text { and } \\
\text { interaction }\end{array}$} & \multicolumn{3}{|c|}{ Seed yields (ardab ${ }^{*} /$ fad) } & \multicolumn{3}{|c|}{ Straw yield (ton/fad) } & \multicolumn{3}{|c|}{ Biological yield (ton/fad) } \\
\hline & $\begin{array}{c}2010 / 201 \\
1 \\
\end{array}$ & $\begin{array}{c}2011 / 201 \\
2 \\
\end{array}$ & Comb & $\begin{array}{c}2010 / 201 \\
1 \\
\end{array}$ & $\begin{array}{c}2011 / 201 \\
2 \\
\end{array}$ & Comb & $\begin{array}{c}2010 / 201 \\
1 \\
\end{array}$ & $\begin{array}{c}2011 / 201 \\
2 \\
\end{array}$ & Comb \\
\hline \multicolumn{10}{|c|}{ A-Gamma irradiation (GY) } \\
\hline Zero & $8.14 d$ & $8.24 d$ & $8.19 \mathrm{~d}$ & $2.28 \mathrm{~d}$ & $2.37 \mathrm{~d}$ & $2.33 \mathrm{~d}$ & $3.50 \mathrm{~d}$ & $3.61 \mathrm{~d}$ & $3.56 \mathrm{~d}$ \\
\hline 15 & $9.55 b$ & $10.73 b$ & $10.14 \mathrm{~b}$ & $2.65 b$ & $2.93 b$ & $2.79 \mathrm{~b}$ & $4.08 \mathrm{~b}$ & $4.54 \mathrm{~b}$ & $4.31 \mathrm{~b}$ \\
\hline 30 & $10.47 \mathrm{a}$ & $11.20 \mathrm{a}$ & $10.84 \mathrm{a}$ & $2.88 \mathrm{a}$ & $3.17 \mathrm{a}$ & $3.03 \mathrm{a}$ & $4.45 \mathrm{a}$ & $4.85 \mathrm{a}$ & $4.65 \mathrm{a}$ \\
\hline 60 & $9.39 \mathrm{c}$ & $10.06 \mathrm{c}$ & $9.73 \mathrm{c}$ & $2.61 \mathrm{c}$ & $2.82 \mathrm{c}$ & $2.72 \mathrm{c}$ & $4.02 \mathrm{c}$ & $4.33 \mathrm{c}$ & $4.18 \mathrm{c}$ \\
\hline F-test & $*$ & $*$ & $*$ & $*$ & * & $*$ & $*$ & $*$ & * \\
\hline \multicolumn{10}{|c|}{ B-Micronutrient application methods } \\
\hline Coating & $8.29 \mathrm{c}$ & $8.56 \mathrm{c}$ & $8.43 \mathrm{c}$ & $2.31 \mathrm{c}$ & $2.43 \mathrm{c}$ & $2.37 \mathrm{c}$ & $3.55 \mathrm{c}$ & $3.71 \mathrm{c}$ & $3.63 \mathrm{c}$ \\
\hline Soaking & $9.35 \mathrm{~b}$ & $10.02 b$ & $9.69 \mathrm{~b}$ & $2.67 \mathrm{~b}$ & $2.87 \mathrm{~b}$ & $2.77 \mathrm{~b}$ & $4.07 \mathrm{~b}$ & $4.37 \mathrm{~b}$ & $4.22 b$ \\
\hline Spraying & $10.52 \mathrm{a}$ & $11.59 \mathrm{a}$ & $11.06 \mathrm{a}$ & $2.83 \mathrm{a}$ & $3.16 \mathrm{a}$ & $3.00 \mathrm{a}$ & $4.41 \mathrm{a}$ & $4.90 \mathrm{a}$ & $4.66 \mathrm{a}$ \\
\hline F-test & $*$ & $*$ & $*$ & $*$ & $*$ & $*$ & $*$ & $*$ & $*$ \\
\hline \multicolumn{10}{|c|}{ C-Micronutrient mixtures } \\
\hline Control & $8.22 \mathrm{c}$ & $8.73 \mathrm{c}$ & $8.48 \mathrm{c}$ & $2.28 \mathrm{c}$ & $2.37 \mathrm{c}$ & $2.33 \mathrm{c}$ & $3.51 \mathrm{c}$ & $3.68 \mathrm{c}$ & $3.60 \mathrm{c}$ \\
\hline $\mathrm{Fe}+\mathrm{Zn}+\mathrm{Mn}$ & $10.50 \mathrm{a}$ & $11.42 \mathrm{a}$ & $10.96 \mathrm{a}$ & $2.88 \mathrm{a}$ & $3.16 \mathrm{a}$ & $3.02 \mathrm{a}$ & $4.46 \mathrm{a}$ & $4.87 \mathrm{a}$ & $4.67 \mathrm{a}$ \\
\hline $\begin{array}{l}\mathrm{Fe}+\mathrm{Zn}+\mathrm{Mn} \\
+\mathrm{Mo}\end{array}$ & $9.44 b$ & $10.02 b$ & $9.73 b$ & $2.65 b$ & $2.94 b$ & $2.80 \mathrm{~b}$ & $4.07 \mathrm{~b}$ & $4.44 b$ & $4.26 \mathrm{~b}$ \\
\hline F-test & $*$ & $*$ & $*$ & $*$ & $*$ & $*$ & $*$ & $*$ & $*$ \\
\hline \multicolumn{10}{|l|}{ Interaction } \\
\hline $\mathrm{AxB}$ & * & * & * & * & * & * & * & * & * \\
\hline $\mathrm{AxC}$ & $*$ & $*$ & * & $*$ & $*$ & $*$ & $*$ & $*$ & $*$ \\
\hline $\mathrm{BxC}$ & $*$ & $*$ & * & $*$ & $*$ & $*$ & $*$ & $*$ & * \\
\hline
\end{tabular}

Ardab $^{*}=150 \mathrm{~kg}$

\section{References}

[1]. Al-Kaisey MT, Mohammed MA, Alwan AKH, Mohammed, MH. (2002): The effect of gamma irradiation on the viscosity of two barley cultivars for broiler chicks. Irradiation Physics and Chemistry 63: 295-297.

[2]. Bakry, B. A., T. A. Elewa, M. F. El karamany, M. S.Zeidan, M. M. Tawfik (2011): Effect of row spacing on yield and its components of some faba bean varieties under newly reclaimed sandy soil condition. World Journal of Agricultural Science 7(1): 68-72.

[3]. Abou El-Yazied, A.(2011): Growth, Biochemical Constituents and Yield of Snap Bean as Influenced by Low Gamma Irradiation Doses under Different Sowing Dates. Australian Journal of Basic and Applied Sciences, 5(11): 30-42.

[4]. Soliman, M.S.A. and M. Abd El-Hamid,(2003): Certain physiological, biological and molecular aspects of kidney bean plants originating from gamma-irradiated seeds during seed germination and plant development, Egypt. J. Rad. Sci. Applic., 16(1): 189211 .

[5]. El-Fouly, M.M., Z.M. Mobarak and Z.A. Salama, (2011).Micronutrients (Fe, Mn, Zn) foliar spray for increasing salinity tolerance in wheat Triticumaestivum L. African Journal of Plant Science. 5(5): 314-322.

[6]. Marschner, H., (1995): Mineral Nutrition of Higher Plants. Academic Press Inc. London LTD.

[7]. El-Akabawy, M.A., M.A. Mahdy, M.M.A. Badr and Nadia O. Monged, (2001): Effect of biofertilizers and micronutrients on the yield and mineral composition of maize plants at different levels of nitrogen.Egypt.J.Appl. Sci., 16(8): 332-344.

[8]. Ashoub, M.A., A.M. Esmail, A.O. Osman and A.S. Osman, (1998): Effect of some microelements application methods under irrigation regime on growth and yield of maize. Arab Univ. J. Agric. Sci. Ain Shams Univ. Cairo, 6(1): $183-192$.

[9]. El-Gizawy, N.K.H., (2000): Response of maize (Zea mays L.) To nitrogen and manganese fertilization. Ph.D. Thesis, Fac. Agric. Moshtohor, Benha Univ.

[10]. Kabata-Pendias, A. And H. Pendias, (1999): Biogeochemistry of Trace Elements. PWN, Warsaw, Poland

[11]. Kanwal, S., A. Rahmatullah, M. Ranjha and R. Ahmad, (2010): Zinc partitioning in maize grain after soil fertilization with zinc sulfate. Int. J. Agric. Biol., 12: 299-302.

[12]. Rego, T.J., K.L. Sahrawat, S.P. Wani and G. Pardhasaradhi, (2007): Widespread deficiencies of sulfur, boron and zinc in Indian semi-arid tropical soils: on-farm crop. J. Plant Nutr., 30: 1569-1583.

[13]. Clarkson, D.T., and Hanson, J.B. (1980). The mineral nutrition of higher plants. Annu. Rev. Plant Physiol. 31, $239-298$.

[14]. Metzner,H.,H.Raw and H. Sengar(1965).UntersuchungenZursychron-isierbarkieteinzelner Pigment mangel-MutantenvonChorella. Planta 65:186.

[15]. Steel, R.G.D.; J.H.Torrie and D.A.Dicky(1997): Principles and procedures of statistics, a biological Approach. 3rd Ed. Macgraw Hill Book Co. New Yourk.

[16]. Gomez,K.A.andA.A.Gomez (1984).Statistical Procedures for Agricultural Res.,Wiley,newyork,USA. 
[17]. Modaihsh,A.S.(1997).Foliar application of chelated and non- chelated metals for supplying micronutrients to wheat grown on calcareous soil.Exp. Agric., 33:237-245.

[18]. Moussa, H. R., (2006). Role of Gamma Irradiation in Regulation of NO3 Level in Rocket (Erucavesicariasubsp. Sativa) Plants. Russian Journal of Plant Physiology, 53: 193-197.

[19]. Salem,H.M. and N.B.EL-Gizawy (2012). Importance of micronutrients and its application methods for improving maize (Zea mays L.) Yield grown in clayey soil. American-Eurasian J.Agric.andEnviron.Sci., 12(7):954-959.

[20]. Hegazi ,A.Z. and N.Hamideldin.(2010).The effect of gamma irradiation on enhacement of growth and seed yield of okra[Abelmoschusesculentus( L.)Monech] and associated molecular changes.J.Hort.and Forestry .2(3):38-51.

[21]. Farg.I.A.A.(1996) .Effect of some environmental factors on certain metabolic Products in (Vicia faba L.) seeds during their development and processing . M.Sc. Thesis, Inst.environ.,stydies and Res., Ain shams Univ. Cairo, Egypt.

[22]. Gaber, A. M. Mostafa, H. A. M. Ramadan, A. A. (2000): Effect of gamma irradiation of faba beans (Vicia faba) plant on its chemical composition, favism causative agents and hormonal levels. Egyptian Journal of Physiological Sciences; 2000, publ. 2002. 24: 1, 1-16.

[23]. Tamas, E. Sestras, R. Muntean, L. (2005): Variability of productivity elements at Vicia faba L. Genotypes after gamma-ray treatment on M3 generation.

[24]. Norfadzrin, O.H. Ahmed, S. Shaharudin and Abdul Rahman,D. (2007): A preliminary study on gamma radiosensitivity of Tomato (Lycopersiconesculentum) and Okra (Abelmoschusesculentus). Int. J.Agric. Res. 2: 620-625.

[25]. Dubey A K, Yadav JR,Singh B (2007).Studies on induced mutations by gamma irradiation in okra [Abelmoschusesculentus (L.)Monch.].ProgressiveAgric. 7(1/2); 46-84.

[26]. Farag,I.A.A .and A.A.H. El-Khawaga.(2013). Influence of gamma irradiation and nitrogen fertilizer levels on gemmeiza-9 wheat cultivar yield and its attributes. Arab J. Nuclear Sic., and Applications, 46 (2):363-371.

[27]. Iman,A.A.FARG and I.M. Abd El-Hameed (2013). Influence of low gamma irradiation doses and weed control on faba bean (Vicia faba L.) Yield and its attributes ZagazigJ.Agric.Res., (40) 1:1-10.

[28]. Sundaravadiveiu k, Ranjithselvip,Reddy VRK(2006).Induced genetic vaiabilty in cotton (Gossypiumhirsutum L) for yield and its components .Crop Res.Hisar.32(3):442-446.

[29]. Sujaya-Das, Anirban-Maji,Puspendu-Singha,Sarkar,kk(2007).Selection of some useful mutants of mungbeanVigna radiate(L) wilczek in generation. Environ. Ecol.255 (Special 2):258-260.

[30]. Khan. M.Z., M E. Akhtar, M.N. Safdar, M.M. Mahmood. S. Ahmad4and N. Ahmed. (2010). Effect of source and level of potash on yield and quality of potato tubers. Pak: .I. Bot., 42(5): 31]7•3145.

[31]. Rahm Din, M.M. Khan, M. Qasim S. Jehan and M.M. Iqbal: (2003); Induced Mutability studies in three wheat (Triticumaestivum L.). Varity for some morphological an agronomic characteristicsasian Journal of Plant Sciences 2: (17-24):1179-1182.

[32]. Singh,B. And P.S. Datta (2010): Effect of low doses of gamma radiation on plant and grain nutrition of wheat; Radiation physics and chemistry. 79: 139-143.

[33]. Abdo, F.A., N.A. Anton and F.R. Hana (2002).The influence of two applying methods of icronutrients mixture with different levels of nitrogen fertilization on sunflower plants grown under sandy soil conditionsj.Agric. Sci., Mansoura Univ., 27(10): 6552-6566.

[34]. Farzanian, M., M. Yarnia, A. Javanshir and A.R. Tarinejhad (2010). Effects of microelements application methods on seed yield components in Alstar sunflower hybrid. J. Of foods, Agric. \&Envi. 8(3\&4): $305-308$.

[35]. Babaeian, M., M. Heidari and A. Ghanbari (2010). Effect of water stress and micronutrient application on physiological characteristics and nutrient uptake in sunflower (Helianthus annuus L.). Iranian J. Crop Sci., 12(4): 377 - 391.

[36]. Ebrahimian, E. And A. Bybordi (2011). Exogenous silicium and zinc increase antioxidant enzyme activity and alleviate salt stress in leaves of sunflower. J. Of foods, Agric. And Envi., 9 (1): 422 - 427.

[37]. Omar,A.E.A. and I.M. Abd El-Hameed (2012). RESPONSE OF SUNFLOWER (Helianthus annuus L.) TO POTASSIUM AND MICRONUTRIENTS FERTILIZATION UNDER DRIP IRRIGATION IN SANDY SOIL ZagazigJ.Agric.Res.,(39) 6: 1069-1081.

[38]. Babaeian, M., A. Tavassoli, A. Ghanbari, Y. Esmaeilian and M. Fahimifard (2011). Effect of foliar micronutrients application on osmotic adjustments, grain yield and yield components in sunflower (Alstar cultivar) under water stress at three stages. African J. Agric. Res., 6 (5): 1202 - 1208. 